\title{
Cotton leafroll dwarf virus detected in Timor-Leste
}

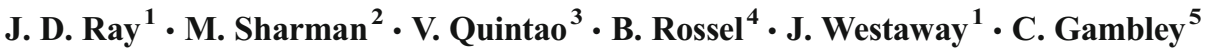

Received: 4 April 2016 / Accepted: 11 October 2016 / Published online: 24 October 2016

(C) Australasian Plant Pathology Society Inc. 2016

\begin{abstract}
Cotton leafroll dwarf virus (CLRDV) is vectored by cotton aphid (Aphis gossypii) and causes Cotton blue disease. This disease results in significant crop losses in commercial cotton (Gossypium hirsutum) from several regions of the world. CLRDV was detected using molecular tools in a sample of Sea island cotton (Gossypium barbadense) collected from Timor-Leste.
\end{abstract}

Keywords Cotton blue disease (CBD) · Cotton leafroll dwarf virus (CLRDV) · Polerovirus · Virus · Plant disease · Cotton · East Timor · Timor-Leste

Cotton blue disease was first described in Africa in 1949, with symptoms in commercial cotton (Gossypium hirsutum) including leaf rolling and moderate to severe stunting of affected plants (Cauquil and Vaissayre 1971). The causal agent, Cotton leafroll dwarf virus (CLRDV) is reported from Brazil, Argentina, India and Thailand (Corrêa et al. 2005; Distéfano et al. 2010; Mukherjee et al. 2012; Sharman et al. 2015). CLRDV (genus Polerovirus, family Luteoviridae) has high

J. D. Ray

jane.ray@agriculture.gov.au

1 Department of Agriculture and Water Resources, PO Box 37846, Winnellie, NT 0821, Australia

2 Department of Agriculture and Fisheries, Ecosciences Precinct, Brisbane, QLD 4075, Australia

3 National Directorate of Quarantine and Biosecurity, Ministry of Agriculture and Fisheries, Comoro, Dili, Timor-Leste

4 Department of Agriculture and Water Resources, GPO Box 858, Canberra, ACT 2601, Australia

5 Department of Agriculture and Fisheries, Applethorpe Research Station, Applethorpe, QLD 4378, Australia sequence similarity to a second, unclassified Luteoviridae member, Chickpea stunt disease-associated virus (CpSDaV) reported from India (Naidu et al. 1997). Although only partial $\mathrm{CpSDaV}$ genome sequence is currently available for comparison, both CLRDV and CpSDaV may be strains of the same species (Distéfano et al. 2010). Both of these important virus strains / species are exotic to Australia.

Plant health surveys in Timor-Leste (East Timor) were collaboratively conducted annually by the Timor-Leste Ministry of Agriculture and Fisheries and the Australian Government Department of Agriculture. These surveys aimed to increase the knowledge of plant pests in Timor-Leste and to identify potential disease threats to Timor-Leste and Australia.

Cotton and chickpea (Cicer arietinum) are not grown commercially in Timor-Leste. There are no Gossypium species indigenous to the island of Timor. However, three introduced species of Gossypium do occur in Timor-Leste as either occasional, very small scale cultivations for cotton, or as subsequently naturalised plants. Plant health surveillance data recently collected in Timor-Leste suggests that Gossypium species (particularly G. barbadense and less so G. hirsutum and G. arboreum) are cultivated in small numbers at the village garden level for cotton lint, as an ornamental plant or a link to past cultural practises. During a plant health survey in May 2013 an asymptomatic sample of $G$. barbadense was collected from Laivai, Lospalos district, Timor-Leste. The sample was desiccated for virus screening, imported into Australia under quarantine permit for analyses and lodged with the Queensland Plant Pathology Herbarium (BRIP no. $62,754)$.

Total nucleic acids were extracted and partial virus genome amplified from the sample by reverse transcription PCR as previously described by Sharman et al. (2015). The CLRDV-specific PCR (primers CLRDV3675F / Pol3982R) produced an amplicon of expected size of approximately 
Table 1 PCR primers used in this study

\begin{tabular}{ll}
\hline Primer name & Sequence $\left(5^{\prime}\right.$ to $3^{\prime}$ ) \\
\hline Pol3197F & CTGGAATTYTGYTCTCAYAT \\
Pol3651R & TTCTASCCRCGRCCGTATTCAT \\
CLRDV3512F & CTGGAYTACAAATTCCTATCAGGATT \\
CLRDV3791R & GCGTCCTCCTGTCCKATTACGA \\
CLRDV3675F $^{\text {a }}$ & CCACGTAGRCGCAACAGGCGT \\
Pol3982R $^{\text {a }}$ & CGAGGCCTCGGAGATGAACT \\
Pol3870F $^{\text {a }}$ & ATCACBTTCGGGCCGWSTYTWTCAGA \\
AS3 $^{\text {b }}$ & CACGCGTCIACCTATTTIGGRTTITG \\
\hline
\end{tabular}

${ }^{\text {a }}$ Published by Sharman et al. (2015)

${ }^{\mathrm{b}}$ Published by Abraham et al. (2008)

$310 \mathrm{bp}$ from the Timor-Leste sample (BRIP no. 62,754), indicating that the virus CLRDV was present in the sample.

The irradiation treatment required by the quarantine import permit, may have affected amplification of large viral genome fragments from sample BRIP no. 62,754. To obtain further virus genome sequence, a range of overlapping PCR primers were designed (Table 1) and overlapping PCR products of the expected sizes from the primer pairs Pol3197F / Pol3651R, CLRDV3512F / CLRDV3791R, CLRDV3675F / Pol3982R and Pol3870F / AS3 were directly sequenced (Australian Genome Research Facility, Brisbane). The resulting consensus sequence was $1005 \mathrm{nt}$ (GenBank accession KT223789) after removal of the outer most primer sequences and consisted of the partial 3' end of the RNAdependent- RNA-polymerase (RdRp) gene, the complete intergenic region (IR) and the almost complete coat protein gene. The closest match by BLAST (Zhang et al. 2000) in GenBank was $97 \%$ nt identity to CpSDaV (accession Y11530) but this Genbank accession for partial CpSDaV genome is only 577 nt. Over the full sequence of the Timor Leste sample the closest match by BLAST was $94 \%$ with the type isolate of CLRDV from Argentina (accession GU167940). A similar level of nt identity was also found when compared to other CLRDV sequences from Thailand, Brazil and India (accessions KP176644, HQ827780 and JN033875).

Sequence alignments and phylogenetic analyses were done as previously described (Sharman et al. 2015). The almostcomplete coat protein gene sequence of 591 nucleotide (nt) from the Timor- Leste sample was analysed to determine phylogenetic relationships to published sequences. Over a 197 amino acid (aa) region, the partial putative coat protein sequence of the Timor-Leste sample was closely related to CLRDV from Thailand (KP176643), India (JN033875), Brazil (HQ827780) and Argentina (GU167940), and CpSDaV from India (Y11530) with between $98 \%$ to $96 \%$ aa identity (Fig. 1). Viruses in the polerovirus genus are considered to be distinct species if they share less than $90 \%$ aa identity in any of the gene products (King et al. 2012). The intergenic region is a known recombination hot-spot in the genomes of Luteoviridae species (Knierim et al. 2010) but there was no evidence for a recombination event in the sequence spanning this region for the Timor-Leste sample. The complete genome sequence will be required to determine if a recombination event may be present elsewhere in the genome. However, the high levels of identity we determined in this study, indicate the Timor-Leste sample is closely

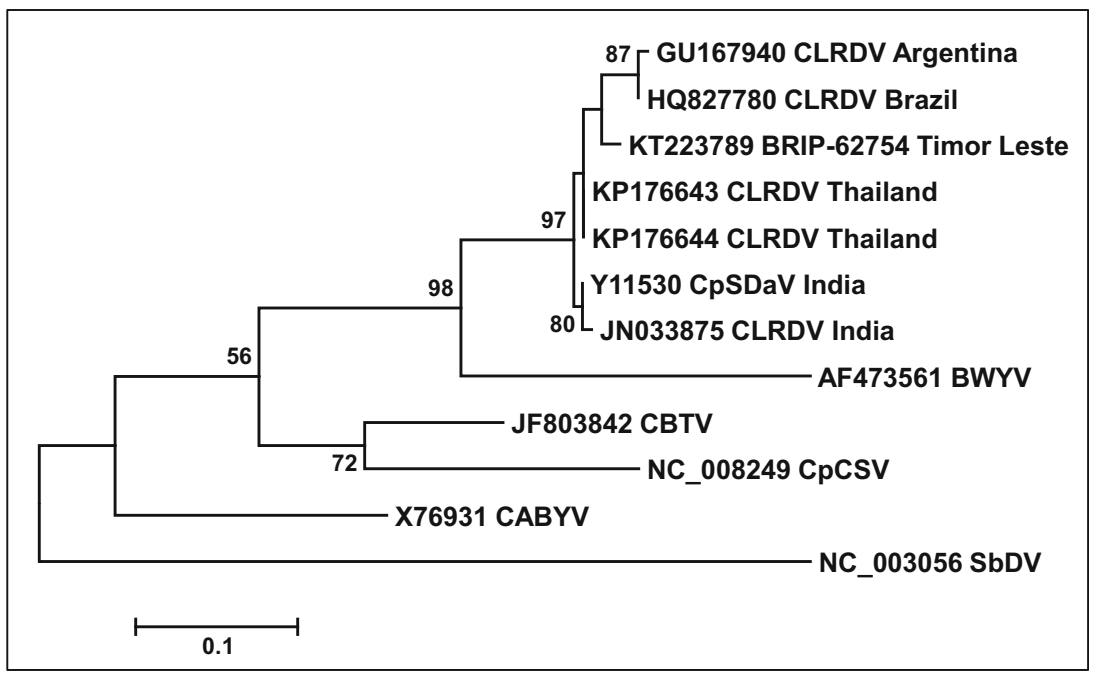

Fig. 1 Phylogram obtained from a Maximum Likelihood analysis for the partial coat protein for a 197 amino acid region from Timor-Leste sample presented in this study (BRIP no. 62,754) and other previously published Luteoviridae members. The scale bar represents the number of amino acid substitutions per site. Maximum likelihood support values (>50\%) are shown at the nodes. Genebank accession numbers are shown on phylogram. Virus abbreviations additional to those presented in the text include BWYV (Beet western yellows virus), CBTV (Cotton bunchy top virus), CpCSV (Chickpea chlorotic stunt virus), CABYV (Cucurbit aphid-borne yellows virus) and SbDV (Soybean dwarf virus) 
related to both CLRDV and CpSDaV and as suggested previously (Distéfano et al. 2010; Corrêa et al. 2005) these may represent strains of one species. However, the ICTV recognises both CLRDV and CpSDaV as species names due to the incomplete genome data for CpSDaV (ICTV 2014). Unless further sequence information becomes available for $\mathrm{CpSDaV}$ which proves otherwise, the virus detected in Timor-Leste should be considered a strain of CLRDV.

This detection of a CLRDV-like sample from TimorLeste represents a significant geographic jump in the distribution of this virus, with the next nearest reported location being Thailand (Sharman et al. 2015). Limited host range data is available for CLRDV but is reported to include several Malvaceae species such as G. hirsutum, G. barbardense, Hibiscus sabdariffa and Sida acuta (Kaowsiri 1982). The reported host range for CpSDaV includes several plants in the Amaranthaceae and Fabaceae families, although symptoms were only reported in chickpea (Reddy and Kumar 2004). If the causal agents CLRDV and $\mathrm{CpSDaV}$ are synonymous then this virus may have a large asymptomatic host range.

Pathogenicity tests using live source plant would determine if the virus collected from asymptomatic G. barbadense in Timor-Leste can cause Cotton blue disease symptoms in G. hirsutum. However, this would require a live source plant, as poleroviruses are only aphid or graft transmissible. The original source plant at Laivai in Timor-Leste has since died, though the virus may persist in host plants nearby.

CLRDV poses a significant threat to the Australian cotton industry. Several native cotton species occur in scattered populations across Northern Australia and the cotton aphid (Aphis gossypii) is widespread in all cotton production regions in Australian. These plants could host viruses such CLRDV and potentially act as an incursion pathway from SE-Asia into Northern Australia through to commercial cotton regions. Some molecular screening of samples has been undertaken from samples collected in northern Australia but no CLRDV has been detected thus far (data not shown). Further surveillance in northern Australia and Timor-Leste is planned to increase our understanding of the biology and prevalence of this virus in these regions.
Acknowledgments Timor-Leste Ministry of Agriculture and Fisheries and the Australian Government Department of Agriculture and Water Resources. Department of Agriculture and Fisheries, Queensland conducted the screening as part of the Cotton Research and Development Corporation funded projects DAQ1405 and DAQ1201.

\section{References}

Abraham AD, Varrelmann M, Vetten HJ (2008) Molecular evidence for the occurrence of two new luteoviruses in cool season food legumes in Northeast Africa. Afr J Biotechnol 7:414-420

Cauquil J, Vaissayre M (1971) La "maladie bleue" du cotonnier en Afrique: transmission de cotonnier à cotonnier par Aphis gossypii glover (the "blue disease" of cotton in Africa: transmission cotton to cotton by Aphis gossypii glover). Coton et Fibres Tropicales 26: 463-466

Corrêa RL, Silva TF, Simões-Araújo JL, Barroso PAV, Vidal MS, Vaslin MFS (2005) Molecular characterization of a virus from the family Luteoviridae associated with cotton blue disease. Arch Virol 150(7): $1357-1367$

Distéfano A, Bonacic Kresic I, Hopp H (2010) The complete genome sequence of a virus associated with cotton blue disease, cotton leafroll dwarf virus, confirms that it is a new member of the genus Polerovirus. Arch Virol 155:1849-1854

ICTV (2014) International Committee on Taxonomy of Viruses Master List 2014 version 4 . http://talk.ictvonline.org/files/ictv documents/m/msl/5208.aspx. Accessed 19/10/2015

Kaowsiri T (1982) Leaf roll disease, the most important disease of cotton. The Journal of Thai Phytopathological Society 2:7-9

King AMQ, Adams MJ, Carstens EB, Lefkowitz EJ (2012) Virus taxonomy: ninth report of the international committee on taxonomy of viruses. Elsevier Acedemic Press, San Diego

Knierim D, Deng TC, Tsai WS, Green SK, Kenyon L (2010) Molecular identification of three distinct Polerovirus species and a recombinant cucurbit aphid-borne yellows virus strain infecting cucurbit crops in Taiwan. Plant Pathol 59:991-1002

Mukherjee AK, Chahande PR, Meshram MK, Kranthi KR (2012) First report of Polerovirus of the family Luteoviridae infecting cotton in India. New Disease Reports 25:22

Naidu RA, Mayo MA, Reddy SV, Jolly CA, Torrance L (1997) Diversity among the coat proteins of luteoviruses associated with chickpea stunt disease in India. Ann Appl Biol 130(1):37-47

Reddy SV, Kumar PL (2004) Transmission and properties of a new luteovirus associated with chickpea stunt disease in India. Curr Sci 86(8):1157-1161

Sharman M, Lapbanjob S, Sebunruang P, Belot JL, Galbieri R, Giband M, Suassuna N (2015) First report of cotton leafroll dwarf virus in Thailand using a species-specific PCR validated with isolates from Brazil. Aust Plant Dis Notes 10(1):1-4

Zhang Z, Schwartz S, Wagner L, Miller W (2000) A greedy algorithm for aligning DNA sequences. J Comput Biol 7:203-214 